\title{
PERAN YAYASAN "SAMIN" DALAM PENCEGAHAN DAN PENANGANAN KEKERASAN ANAK DALAM KELUARGA \\ (Kasus Peran Yayasan "SAMIN" dalam Pencegahan dan Penanganan Kekerasan Anak dalam Keluarga di Kabupaten Sleman, D.I.Y)
}

\author{
Nadya Tamara Dewaanjani ${ }^{1}$, Sudarsana ${ }^{2}$ \\ Program Studi Sosiologi Fakultas Ilmu Sosial dan Politik \\ Universitas Sebelas Maret Surakarta Indonesia \\ Email1: raratamara7@gmail.com,Email²: sudarsana@staff.uns.ac.id
}

\begin{abstract}
Family is one of the social institutions in the community. Family is also a place for children to acquire mental coaching and personality formation. The family has a considerable role and function on the development and future of the child. However, in fact the violence of children in the family often occurs, such as violence involving fathers, mothers and other siblings. Lack of knowledge and insight related to parenting, growth and development of children is one factor in the occurrence of violence against children. From various cases of child violence, one of NGO named Yayasan SAMIN that cares about child issues to make efforts to prevent and treat child violence in the family. This research aims to know 1) how the role of Yayasan SAMIN in the prevention and handling of child violence in the family, 2) How to form the prevention and handling conducted by the Yayasan SAMIN against Child abuse cases in Family. The results of this study show that 1) Yayasan SAMIN has been explaining its role in the prevention of child violence against parents and the treatment of child abuse victims in families, 2) The prevention of child violence by parents is socialization, campaigning, and KIE (communication, information, education). The form of treatment of victims of violence is with mentoring.
\end{abstract}

Keywords: family, child violence, NGO

Abstrak: Keluarga merupakan salah satu lembaga sosial yang ada di masyarakat. Keluarga juga merupakan tempat bagi anak untuk memperoleh pembinaan mental dan pembentukan kepribadian. Keluarga memiliki peran dan fungsi yang cukup besar terhadap perkembangan dan masa depan anak. Namun, pada faktanya munculnya kekerasan pada anak dalam keluarga sering terjadi, antara lain kekerasan yang melibatkan pihak ayah, ibu dan saudara yang lainnya. Kurangnya pengetahuan dan wawasan yang berhubungan dengan pengasuhan, pertumbuhan dan perkembangan anak merupakan salah satu faktor terjadinya kekerasan terhadap anak. Dari berbagai kasus kekerasan terhadap anak, munculah salah satu NGO yaitu Yayasan SAMIN yang peduli terhadap isu-isu anak untuk melakukan upaya pencegahan dan penanganan terhadap kekerasan anak dalam keluarga. Penelitian ini bertujuan untuk mengetahui 1) bagaimana peran Yayasan SAMIN dalam melakukan pencegahan dan penanganan kekerasan anak dalam keluarga, 2) bagaimana bentuk pencegahan dan penanganan yang dilakukan Yayasan SAMIN terhadap kasus kekerasan anak dalam keluarga. 
Penelitian ini menggunakan Teori Perilaku Sosial Operant Conditioning dari B.F. Skinner. Penelitian ini menggunakan metode penelitian desktiptif kualitatif. Teknik yang digunakan dalam pengambilan sampel yaitu snowball sampling dengan menentukan informan secara acak yang mulanya berjumlah sedikit lama-lama menjadi besar. Validitas yang digunakan dalam penelitian ini adalah triangulasi sumber dan triangulasi teknik.

Hasil penelitian ini menunjukkan bahwa 1) Yayasan SAMIN telah menjelankan perannya dalam melakukan pencegahan kekerasan anak terhadap orang tua dan penanganan terhadap anak korban kekerasan dalam keluarga, 2) bentuk pencegahan kekerasan anak oleh orang tua adalah dengan sosialisasi, kampanye, dan KIE (Komunikasi, Informasi, Edukasi). Bentuk penanganan terhadap anak korban kekerasan yaitu dengan pendampingan.

Kata kunci: Keluarga, Kekerasan Anak, NGO

\section{PENDAHULUAN}

Keluarga merupakan salah satu lembaga sosial yang ada di masyarakat. Hampir setiap orang dilahirkan dalam keluarga dan juga membentuk keluarganya sendiri. hampir tidak ada peran tanggung jawab keluarga yang dapat diwakilkan kepada orang lain, seperti halnya tugas khusus dalam pekerjaan dapat diwakilkan kepada orang lain. Keluarga juga merupakan dasar pembantu utama struktur sosial yang lebih luas. Peran tingkah laku yang dipelajari di dalam keluarga merupakan contoh peran tingkah laku yang diperlukan pada segi-segi lainnya dalam masyarakat.

Burgess dan Locke mengemukakan terdapatnya 4 karakteristik keluarga yang terdapat pada semua keluarga dan juga untuk membedakan keluarga dari kelompok-kelompok sosial lainnya, yaitu : (1) Keluarga adalah susunan orang-orang yang disatukan oleh ikatan-ikatan perkawinan, darah atau adopsi. Pertalian antara suami dan istri adalah perkawinan; dan hubungan antara orang tua dan anak biasanya adalah darah dan kadangkala adopsi; (2) Anggota-anggota keluarga ditandai dengan hidup bersama di bawah satu atap dan merupakan susunan satu rumah tangga, atau jika mereka bertempat tinggal, rumah tangga tersebut menjadi rumah mereka; (3) Keluarga merupakan kesatuan dari orang-orang yang berinteraksi dan berkomunikasi yang menciptakan peranan-peranan sosial bagi si suami dan istri, ayah dan ibu, putra dan putri, saudara laki-laki dan saudara perempuan; (4) Keluarga adalah pemelihara suatu kebudayaan bersama, yang diperoleh pada hakekatnya dari kebudayaan umum, tetapi dalam suatu masyarakat yang kompleks masing-masing keluarga mempunyai ciri-ciri yang berlainan dengan keluarga lainnya (Khairuddin, 2008 : 6-7)

Kekerasan anak sering diartikan dengan kata child abuse. Secara teoritis Gelles (1985) mendefinisikan child abuse sebagai peristiwa pelukaan fisik, mental atau seksual yang umumnya dilakukan oleh oorang-orang yang mempunyai tanggung jawab terhadap kesejahteraan anak, yang mana itu semua diindikasikan dengan kerugian dan ancaman terhadap kesehatan dan kesejahteraan anak. 
Berdasarkan data pengaduan Komisi Perlindungan Anak Indonesia (KPAI) dalam 7 tahun terakhir, ditemukan sebanyak 26.954 kasus anak berdasarkan 9 klaster, 3 klaster diantaranya merupakan kasus yang paling tertinggi. Pada tahun 2017, Komisioner KPAI Jastra Putra menyebutkan, pertama kasus anak berhadapan dengan hukum baik pelaku maupun korban 9266 kasus, kedua kasus di keluarga dan pengasuhan alternatif baik korban perceraian orang tua, perebutan hak asuh dan kasus penelantaran ada 5006, ketiga kasus serta Pornografi dan Cyber Crime baik sebagai korban maupun pelaku 2358 kasus. Sepanjang tahun 2017, sebanyak 3.849 kasus kekerasan terhadap anak dilaporkan ke Komisi Perlindungan Anak Indonesia (KPAI). Menurut Ketua KPAI, Susanto pengaduan di tahun 2015 cukup tinggi dengan 4.309 kasus dan yang paling tinggi pada tahun 2016 ada 4.647 kasus. (https://www.kpai.go.id/berita/kpai-riset-kekerasan-di-media-picu-anak-jadi-pelakukejahatan/)

Kasus kekerasan terhadap anak banyak kita jumpai di Kabupaten Sleman, D.I.Y. Berdasarkan data dari Dinas Pemberdayaan Perempuan dan Perlindungan Anak, Pengendalian Penduduk dan Keluarga Berencana (DP3AP2KB) Kabupaten Sleman melalui UPT Pusat Pelayanan Terpadu Perlindungan Perempuan dan Anak (UPT P2TP2A). Kabupaten Sleman mencatat jumlah korban terhadap perempuan dan anak dan kekerasan dalam rumah tangga mencapai 471 kasus. Perempuan dan anak rentan menjadi korban kekerasan baik didalam rumah tangga maupun diluar rumah tangga. Bentuk kekerasan yang dialami korban KDRT maupun non-KDRT paling banyak adalah kekerasa psikis yaitu 200 kekerasan, 130 kekerasan fisik, 62 kasus kekerasan seksual, 36 penelantaran rumah tangga, dan eksploitasi ada 10 korban dan 33 kekerasan lainnya meliputi anak yang terlibat pencurian, anak mogok sekolah, tawuran pelajar dan pengasuhan anak. Meski angka kekerasan di Kabupaten Sleman tinggi namun dari tahun 2015 ke 2017 cenderung menurun, dari tahun 2015 tercatat 539 korban, 2016 ada 499 korban dan 2017 ada 471 korban. Penyebab terjadinya kekerasan terhadap anak antara lain karena pengaruh teknologi informasi yang berkembang pesat, makin bebasnya pergaulan remaja, kurangnya pemahaman orang tua mengenai pola asuh anak yang baik dan benar.

Dari berbagai permasalahan pada anak tersebut, berbagai kalangan hadir untuk membantu dalam penyelesaian pada anak. Mulai dari pemerintah yang mengeluarakan undang-undang tentang perlindungan anak, munculnya regulasi tentang Kabupaten/ Kota Layak Anak (KLA), berdirinya Komisi Perlindungan Anak Indonesia (KPAI). Disisi lain mulai berdirinya Lembaga Swadaya Masyarakat (LSM) ataupun organisasi sosial untuk membantu menyelesaikan kasus-kasus anak. Organisasi non-formal yang terbentuk di Yogyakarta tentang Perlindungan Anak salah satunya adalah Yayasan "SAMIN". Yayasan "SAMIN" (Sekretariat Anak Merdeka Indonesia) adalah organisasi non-pemerintah (NGO) yang fokus dengan isu anak. Yayasan "SAMIN" berdiri pada tanggal 20 Mei 1987 dan awalnya memposisikan diri sebagai support group (lembaga yang memeberikan dukungan kepada pihak lain dalam mengembangkan program-program anak) untuk mendorong kepedulian berbagai pihak terhadap isu-isu anak dan mendukung pihak-pihak yang bermaksud mengembangkan program untuk anak. 


\section{METODE PENELITIAN}

Jenis penelitian ini adalah penelitian kualitatif deskriptif, yaitu data yang dikumpulkan berbentuk kata-kata, gambar, bukan angka-angka yang disebabkan oleh adanya penerapan metode kualitatif (Moleong, 2007 : 11). Menurut Bogdan dan Taylor, penelitian kualitatif adalah prosedur penelitian yang menghasilkan data deskriptif berupa kata-kata tertulis atau lisan dari orang-orang dan perilaku yang diamati (Moleong, 2000 : 3) Teknik pengambilan sampel yang digunakan dalam penelitian ini adalah teknik snowball sampling. Teknik pengumpulan data yang digunakan adalah observasi, wawancara dan dokumentasi. Validitas yang digunakan dalam penelitian ini adalah triangulasi sumber.

\section{HASIL DAN PEMBAHASAN}

Penegasan hak anak dalam UU No. 23 Tahun 2002 ini merupakan legalisasi hak-hak anak yang diserap dari KHA dan norma hukum nasional. Dengan demikian, Pasal 4 s/d 19 UU No. 23 tahun 2002 menciptakan norma hukum (legal norm) tentang apa yang menjadi hak-hak anak. Hak anak atas hidup, tumbuh kembang, perlindungan dan partisipasi secara wajar (Joni : 11).

a. Hak untuk dapat hidup, tumbuh, berkembang, dan berpartisipasi secara wajar sesuai dengan harkat dan martabat kemanusiaan, serta mendapat perlindungan dari kekerasan dan diskriminasi (Pasal 4). Sejalan dengan KHA, hak hidup bagi anak ini, dalam wacana instrumen/konvensi internasional merupakan hak asasi yang universal, dan dikenali sebagai hak yang utama (supreme right). Sedangkan hak atas tumbuh kembang diturunkan ke dalam hak atas kesehatan, pendidikan, dan hak untuk berekspresi, dan memperoleh informasi. Dalam UU No. 23/2002, turunan hak atas tumbuh kembang ini diwujudkan dalam penyelenggaraan perlindungan dalam bidang pendidikan, kesehatan, dan sosial, termasuk agama.

b. Hak untuk tumbuh dan berkembang (development), termasuk didalamnya adalah hak untuk mendapat pendidikan, informasi, waktu luang, berkreasi seni dan budaya. Termasuk pula di dalamnya hak asasi untuk anak cacat (berkebutuhan khusus), mereka juga berhak mendapat perlakuan dan pendidikan khusus.

c. Hak untuk memperoleh perlindungan (protection), perlindungan dari segala bentuk eksploitasi, perlakuan kejam dan sewenang-wenang.

d. Hak untuk berpartisipasi (participation), termasuk hak kebebasan menyampaikan pendapat, berserikat dan berkumpul serta ikut serta dalam pengambilan keputusan yang menyangkut atau mempengaruhi dirinya.

Secara teoritis, kekerasan terhadap anak (child abuse) dapat didefinisikan sebagai peristiwa pelukaan fisik, mental, atau seksual yang umumnya dilakukan oleh orang - orang yang memiliki tanggung jawab terhadap kesejahteraan anak, yang mana itu semua diindikasikan dengan kerugian dan ancaman terhadap kesehatan dan kesejahteraan anak. Contoh paling jelas dari tindakan kekerasan yang dialami anak-anak adalah pemukulan atau penyerangan secara fisik berkali-kali sampai terjadi luka atau goresan. Namun demikian, perlu disadari bahwa child abuse sebenarnya tidak hanya berupa pemukulan atau 
penyerangan fisik, melainkan juga bisa berupa berabgai bentuk eksploitasi melalui pornografi dan penyerangan seksual (sexual assault), pemberian makanan yang tidak layak bagi anak atau makanan kurang gizi (malnutrition), pengabaian pendidikan dan kesehatan (educational and medical neglect) dan kekerasan yang berkaitan dengan medis (Suyanto, 2010:28). .

Henry Kempe menyebut kasus kasus penelantaran dan penganiayaan yang dialami anak - anak dengan istilah Batered Child Syndrome yaitu: "setiap keadaan yang disebabkan kurangnya perawatan dan perlindungan terhadap anak oleh orangtua atau pengasuh lain." Disini yang diartikan sebagai tindak kekerasan terhadap anak tidak hanya luka berat saja, tetapi termasuk juga luka memar atau membengkak sekalipun dan diikuti kegagalan anak untuk berkembang baik secara fisik maupun intelektualnya (Suyanto, 2010:27).

Suharto (1997) mengelompokkan child abuse menjadi empat, yaitu :

1) Physical abuse

Kekerasan anak secara fisik, adalah penyiksaan, pemukulan dan penganiayaan terhadap anak, dengan atau tanpa menggunaka benda-benda tertentu yang menimbulkan luka-luka fisik atau kemerahan pada anak.

2) Psychological abuse

Kekerasan anak secara psikis, meliputi penghardikan, penyampaian kata-kata kasar dan kotor, memperlihatkan buku, gambar, dan film pornografi pada anak.

3) Sexual abuse

Kekerasan anak secara seksual, dapat berupa perlakuan prakontak seksual antara anak dengan orang dewasa (melalui kata, sentuhan, gambar visual, exhibitionism), maupun perlakuan kontak seksual secara langsung antara anak dengan orang dewasa (incest, perkosaan, eksploitasi seksual).

4) Social abuse

Kekerasan anak secara sosial, dapat mencakup penelantaran anak dan eksploitasi anak. Penelantaran anak adalah sikap dan perlakuan orang tua yang tidak memberikan perhatian yang layak terhadap proses tumbuh kembang anak.

\section{Kekerasan Terhadap Anak oleh Orang Tua}

\section{a. Kekerasan Fisik}

Kekerasan fisik adalah kekerasan yang terjadi pada saat anak menerima pukulan dari orang tua. Kekerasan jenis ini biasanya akan diingat oleh anak apalagi akibat dari kekerasan tersebut meninggalkan bekas. Terdapat berbagai macam bentuk kekerasan anak secara fisik yaitu penganiayaan terhadap anak dengan atau tanpa menggunakan benda-benda tertentu yang menimbulkan luka-luka fisik atau bahkan kematian pada anak. bentuk luka dapat berupa lecet atau memar akibat sentuhan atau kekerasan benda tumpul. Kekerasan fisik biasanya terjadi ketika anak nakal, rewel atau lain sebagainya.

Dampak dari adanya kekerasan fisik terhadap anak yang dilakukan oleh orang tua, anak akan mengalami trauma terhadap sentuhan orang lain apabila sering dipukul oleh orang tuanya, anak akan menjadi lebih agresif dari sebelumnya.

\section{b. Kekerasan Psikis}


Kekerasan psikis merupakan kekerasan yang tidak memberikan bekas yang terlihat jelas bagi orang lain atau tidak kasat mata, sehingga pelaku dari kekerasan tersebut salah satunya orang tua tidak menyadari bahwa mereka telah melakukan tindakan kekerasan psikis kepada anak. Bentuk spesifik dari kekerasan psikis ini adalah menggunakan kata-kata kasar atau kotor di mana hal ini snagat mudah diingat oleh anak.

Dampak dari kekerasan secara psikis dapat merusak mental anak, anak akan menjadi tertutup terhadap lingkungan luar, tidak mau bergaul dengan siapapun, merasa bahwa dirinya selalu terintimidasi, mengucilkan diri. anak yang mengalami kekerasan secara psikis, anak tersebut akan menjadi anak dengan karakter yang berbeda, anak akan menjadi pendiam, menutup diri dengan lingkungannya, bahkan bisa mencapai tingkat depresi dan membuat sang anak bunuh diri.

\section{Peran Yayasan SAMIN dalam Pencegahan dan Penanganan Kekerasan Anak dalam Keluarga}

\section{a. Pencegahan}

Dalam melakukan tugasnya sebagai organisasi yang bergerak dalam perlindungan anak, Yayasan SAMIN telah melakukan berbagai upaya pencegahan dan penanganan kekerasan anak. upaya pencegahan yang dilakukan Yayasan SAMIN berupa memberikan sosialisasi tanpa henti kepada masayarakat atau khalayak mengenai pengetahuanpengetahuan dasar tentang Perlindungan Anak, Hak Anak, UUPA, Kekerasan Anak dan lain sebagainya, hal ini dilakukan untuk mencegah terjadi kekerasan kepada anak di masa yang akan datang, selain itu Yayasan SAMIN juga mengajak Forum Anak berkampanye mengenai pencegah melakukan ekploitasi terhadap anak di masyarakat. Dengan media KIE (Komunikasi, Informasi dan Edukasi). Melalui komunkasi, Yayasan SAMIN melakukan kegiatan komunikasi terhadap anak tentang apa yang mereka alami dan rasakan, kemudian dari informasi yang didapat tersebut Yayasan SAMIN melakukan parrenting terhadap orang tua. Dengan informasi, Yayasan SAMIN meneruskan informasi yang dia dapat melalui media sosial seperti facebook, twitter, instagram dan website. Selain itu Yayasan SAMIN juga mengundang media untuk memberikan informasi terkait kegiatan yang dilakukan Yayasan SAMIN dalam pencegahan kekerasan anak oleh orang tua. Edukasi, Yayasan SAMIN melakukan perubahan perilaku kepada masyarakat setelah adanya sosialisasi ke arah yang lebih baik serta melakukan pembentukan komunias-komunitas jaringan agar memiliki peranan dalam perlindungan anak. Yayasan SAMIN mengedukasi masyarakat untuk melakukan tindakan perlindungan anak berupa pencegahan kekerasan terhadap anak.

\section{b. Penanganan}

Penanganan terhadap anak korban kekerasan seperti memberikan dukungan psikologis, membantu penyembuhan trauma berat dengan mendatangkan psikiater, serta 
mempertemukan korban dengan korban lainnya agar saling memberikan support dan tidak berlarut-larut dalam kesedihan.

\section{Faktor Pendukung Terjadinya Kekerasan Anak dalam Keluarga}

Kekerasan yang dialami oleh anak tidak semata-mata terjadi begitu saja, ada faktor yang melatarbelakangi atau menyebabkan hal tersebut bisa terjadi. Dari penelitian yang dilakukan, penulis menemukan adanya faktor internal dan faktor eksternal penyebab terjadinya kekerasan anak dalam keluarga. Faktor internal adalah faktor dari dalam keluarga itu sendiri yang menyebabkan kekerasan. Faktor internal tersebut adalah disfungsi keluarga, pola asuh orang tua yang salah terhadap anak. Selain faktor internal, terdapat faktor eksternal penyebab kekerasan terhadap anak, yaitu faktor ekonomi, gaji yang pas-pas an didapat oleh orang tua tidak sebanding dengan meningkatnya kebutuhan sekarang, hal tersebut dapat menyebabkan konflik dan dapat menjadikan anak sebagi korban dari kekerasan.

\section{PENUTUP}

Hasil penelitian ini menunjukkan bahwa 1) Yayasan SAMIN telah menjelankan perannya dalam melakukan pencegahan kekerasan anak terhadap orang tua dan penanganan terhadap anak korban kekerasan dalam keluarga, 2) bentuk pencegahan kekerasan anak oleh orang tua adalah dengan sosialisasi, kampanye, dan KIE (Komunikasi, Informasi, Edukasi). Bentuk penanganan terhadap anak korban kekerasan yaitu dengan pendampingan.

Upaya pencegahan yang dilakukan Yayasan SAMIN berupa memberikan sosialisasi tanpa henti kepada masayarakat atau khalayak mengenai pengetahuan-pengetahuan dasar tentang Perlindungan Anak, Hak Anak, UUPA, Kekerasan Anak dan lain sebagainya, hal ini dilakukan untuk mencegah terjadi kekerasan kepada anak di masa yang akan datang, selain itu Yayasan SAMIN juga mengajak Forum Anak berkampanye mengenai pencegah melakukan ekploitasi terhadap anak di masyarakat. Dengan media KIE (Komunikasi, Informasi dan Edukasi). Melalui komunkasi, Yayasan SAMIN melakukan kegiatan komunikasi terhadap anak tentang apa yang mereka alami dan rasakan, kemudian dari informasi yang didapat tersebut Yayasan SAMIN melakukan parrenting terhadap orang tua.

\section{DAFTAR PUSTAKA}

Adi Fahrudin, dkk. 2016. Child Abuse and Neglect: Psychological Impact and Role of Social Work. International Journal of Social Work. 3(1) : $65-75$

J. Moleong, Lexy. 2000. Metode Penelitian Kualitatif. Bandung: Remaja Rosdakarya.

Khairudin. 2008. Sosiologi Keluarga Cet. 2. Yogyakarta : Liberty

Miftah, Thoha. 1997. Kepemimpinan Dalam Manajemen Suatu Pendekatan Perilaku. Jakarta : Kaya Safrindo Pustaka

Moleong, Lexy J. 2007. Metodologi Penelitian Kualitatif. Bandung : PT Remaja Rosdakarya Offset

Rabiah Al Adawiah. 2015. Upaya Pencegahan Kekerasan Terhadap Anak. Jurnal Keamanan Nasional. 1(2) 
Soekanto, Soerjono. 2002. Teori Peranan. Jakarta : Bumi Aksara.

Suyanto, Bagong,dkk. 2000. Krisis Ekonomi dan Pengembangan Anak Rawan dalam buku :

Seandainya Aku Bukan Anakmu. Editor: St. Sularto. Jakarta: Kompas

Suyanto, Bagong. 2010. Masalah Sosial Anak. Jakarta: Kencana

Undang-undang Nomor 23 Tahun 2002 tentang Perlindungan Anak. 